\title{
EquiLIBRIUM
}

Quarterly Journal of Economics and Economic Policy

2015 VOLUME 10 ISSUE 1, March

p-ISSN 1689-765X, e-ISSN 2353-3293

www.economic-policy.pl

Jonek-Kowalska, I. (2015). State Aid and Competitiveness of the Hard Coal Mining Industry in the European Union. Equilibrium. Quarterly Journal of Economics and Economic Policy, 10(1), pp. 69-87, DOI: http://dx.doi.org/10.1 2775/EQUIL.2015.004

\section{State Aid and Competitiveness of the Hard Coal Mining Industry in the European Union**}

JEL Classification: D22; E65; F30; F60

Keywords: state aid; competitiveness of industries; hard coal mining industry in Poland and the EU; Polish mining enterprises

\begin{abstract}
The hard coal mining industry in the European Union (EU) is in decline, mostly due to a lack of price competitiveness. It is maintained, to a great extent, by state aid; the key objective of the industry's existence is to provide energy security and guarantee employment in the mining regions. In Poland, the hard coal mining industry is currently undergoing a serious crisis that threatens the two largest mining enterprises with bankruptcy. In addition, due to the European Union's restrictions concerning the circumstances of granting state aid, these enterprises cannot count on the financial support for the repair restructuring that they used on a large scale until 2011. Therefore, in this article, the main objective is to determine the influence of state aid on the competitiveness of the hard coal mining industry in 12 countries of the EU, including Poland in specific. In order to achieve the stated objective, the article is divided into three parts. The first part consists of a literature review, and legal regulations that are related to state aid for the hard coal mining industry in the EU are presented. The second part identifies the amount of state aid for the mining industry in the examined countries. Next,
\end{abstract}

(C) Copyright Institute of Economic Research \& Polish Economic Society Branch in Torun Date of submission: December 13, 2014; date of acceptance: February 5, 2015

* Contact: izabela.jonek-kowalska@polsl.pl, The Silesian University of Technology, Faculty of Organization and Management, ul. Roosevelta 26, 41-800 Zabrze, Poland

** The article was financed from BK-216/ROZ-1/2014. 
the economic effects of state aid for hard coal mining in the European Union are examined. The third assesses the financial results of 24 Polish hard coal mines.

\section{Introduction}

The role of the state in the theory of economy may be analyzed and evaluated within the frames of two main research trends that differ in their approach to the effectiveness of influence of the state on real values in economy. Accordingly, in the neoclassical trend that was derived from the classical school, a minimal range of state intervention in the economy is advised - it is reduced to providing law obedience and security, as well as to prevent monopoly (Balcerzak \& Rogalska, 2010; Stankiewicz, 2000, pp. 163-164; Smandek, 1993, pp. 9). In turn, in the Keynesian trend, state intervention is acceptable in the market mechanism, due to its disability and lack of optimality in business and household decisions in a short-term period (Wojtyna, 2000, pp. 70-76; Spychalski, 2002, pp. 2502-255; Zieliński, 2008, pp. 20-27).

In this article, an attempt is made to conduct an effectiveness assessment of state intervention in the industrial restructuring of hard coal mining in the EU. In many contemporary types of research on restructuring efficiency and effectiveness in state-owned sectors, it is emphasized that the restructuring objectives are more often fully achieved in case of private enterprises. State ownership disturbs the process of resources allocation, slows down management initiatives and delays investment decisions, which makes proper functioning impossible in a liberalized and competitive economic environment (Balcerzak, 2009; Piech, 2009; Kam, et al., 2008, pp. 567-579; Apostolov, 2013, pp. 680-691). The restructuring process of stateowned enterprises is also disrupted for political reasons of the decisions made (Bhattacharyya, 2007, pp. 317-332; Apostolov, 2011, pp. 124-134).

In the period analyzed in the article, which encompasses the years 20002012 , the hard coal mining industry in the EU was systematically subsidized within the frames of the EU Council Regulation no. 1407/2002 on 23 July 2002, which pertains to state aid for the coal industry. According to the regulation, retaining domestic energy security justified state aid granting for unprofitable hard coal mines (Olkuski, 2011, pp. 42-45). However, financial support for the mining industry concerned a wide subject range, which included aid for the closure of unprofitable mines, operating aid, investment aid (Michalak, 2012, pp. 11-22; Michalak, 2012, pp. 267-276) and aid for extraordinary costs that were inherited and connected to sector restructuring (Paszcza \& Białas, 2009, pp. 135-156). 
The state aid categories for hard coal mining that are listed above were limited in the decision of the European Commission on state aid to facilitate the closure of uncompetitive coal mines (2010/787/UE). According to the decision, these days state aid may only be granted for: 1 . the costs of closing unprofitable mines, also including current production losses, provided that the mines will have been finally closed down by 31 December 2018 , 2. extraordinary costs financed until the end of 2026, mostly connected with social costs (pensions and employee benefits for dismissed staff) and technical ones (securing infrastructure of liquidated mines). Consequently, support for initial investment and state aid without time limits were dropped, which hinders the domestic initiatives concerning the improvement of sector's competitiveness (Białas, 2011, pp. 7-28; Gorczyńska \& Szwajca, 2012, pp. 23-29).

\section{Methodology of the Research}

The main purpose of the article and the research that was conducted was to perform the assessment and comparative analysis of the results of the hard coal mining industry in the countries of the EU in which hard coal mining was subsidized by public resources (Anderson, 1995, pp. 485-496; Frondel et al., 2007, pp. 3807-3814). The author of the article is also searching for an answer to the following research questions:

- Which countries, in the years 2000-2012, granted the highest amounts of state aid to the hard coal mining industry? Has such a move found its reflection in the economic and quality results of the examined industries?

- What are the development perspectives of the Polish hard coal mining in the light of the current EU regulations concerning state aid for the industry and in the context of the current economic situation of the Polish mines?

Because of two types of threads in the questions above, the research part of the article was divided into two stages. The first stage includes a comparative analysis of state aid granted for the mining industry from public resources. The second stage encompasses the results of measurement and analysis of effectiveness in 24 Polish hard coal mines from 2005-2012, together with the assessment of the perspectives of their further functioning in the structures of two largest state-owned mining enterprises.

The research methodology is of interdisciplinary character and contains the ratios typical for economic analysis and for the assessment of hard coal reserves and quality in the mining industry. The detailed information on the 
universal and special ratios that were used - constructed for the purpose of the research conducted - is presented in Figure 1.

Figure 1. Ratios used in the research methodology

\section{Research activity}

Characteristics of hard coal mining

Assessment of the scale of state aid for hard coal mining industry
Method of measurement

size of geological deposits [Mt]

amount of resource reserves possessed [Mt] employment [people]

amount of state aid [in millions of euro]

structure of state aid by beneficiaries [\%] state aid calculated per ton of resource mined (author's ratio) [euro/ton]

\section{sulfur content $[\%]$}

ash content $[\%]$

calorific value $[\mathrm{kJ} / \mathrm{kg}]$

value added [in millions of euro] ratio of the average annual value added to state aid received (author's ratio) [\%] wage adjusted labour productivity [\%] average personnel costs [thousands euro]

gross operating rate [\%]

Assessment of economic parameters in the industry

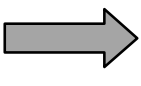

\section{gross margin on sales [\%]}

Effectiveness assessment of mines in Polish hard coal mining

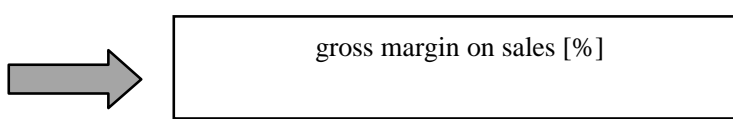

Source: own work.

In the research, there are statistical data that come from Eurostat and Euracoal databases, as well as data obtained during the author's research carried out in 24 hard coal mines that belong to the two largest Polish mining enterprises. 


\section{State Aid For the Hard Coal Mining Industry in the European Union}

The hard coal mining industry in the EU is an industry that is systematically subsidized by state funds, and economic and social-political priorities have been competing with one other for many years in the industry. On the one hand, it is an industry that is characterized by low and decreasing price competitiveness, thus making efficient competitive struggle impossible. On the other hand, it is an industry that provides thousands of jobs in the mining regions and/or additionally guarantees energy security (Miller, 2011, pp. 1-51). The characteristics of the working and potential coal deposits (reserves), together with the number of people employed in the mining industry, in the examined countries of the EU is presented in Table 1.

The results from the data included in Table 1 indicate that Poland possesses the largest deposits of hard coal. Significant, but smaller hard coal deposits are also found in Germany and Great Britain. In turn, the largest lignite deposits are located in Poland, Germany and Hungary. Lignite is a kind of fuel that Germany, Poland and Greece (Kavouridis, 2008, pp.1257-1272; Roch, 2009, pp. 857-867) have at their disposal to the largest potential extent. Polish hard coal mining employs 113 thousand people, which is a record value in the listing presented. In Germany, the mining enterprises employ about 34 thousand workers and, in Great Britain (Lorenz, 2009), almost 6 thousand people. In connection with the above, the greatest social threat would be even a partial liquidation of hard coal mining in Poland within the Upper Silesian Coal Basin (Zieliński, 2013, pp. 137-143). It is worth mentioning that, in Germany and Great Britain, employment in the hard coal mining industry has been systematically reduced in the last few years, just as in France and Spain (Fernández, 2000, pp. 537547), which are the countries that formerly led the production of hard coal in Europe. The countries listed in Table 1 may use state aid as a matter of law in force in the EU. The value of state aid granted from 2000-2012 is presented in Table 2 and the structure in division into the particular countries is listed in Table 3. 


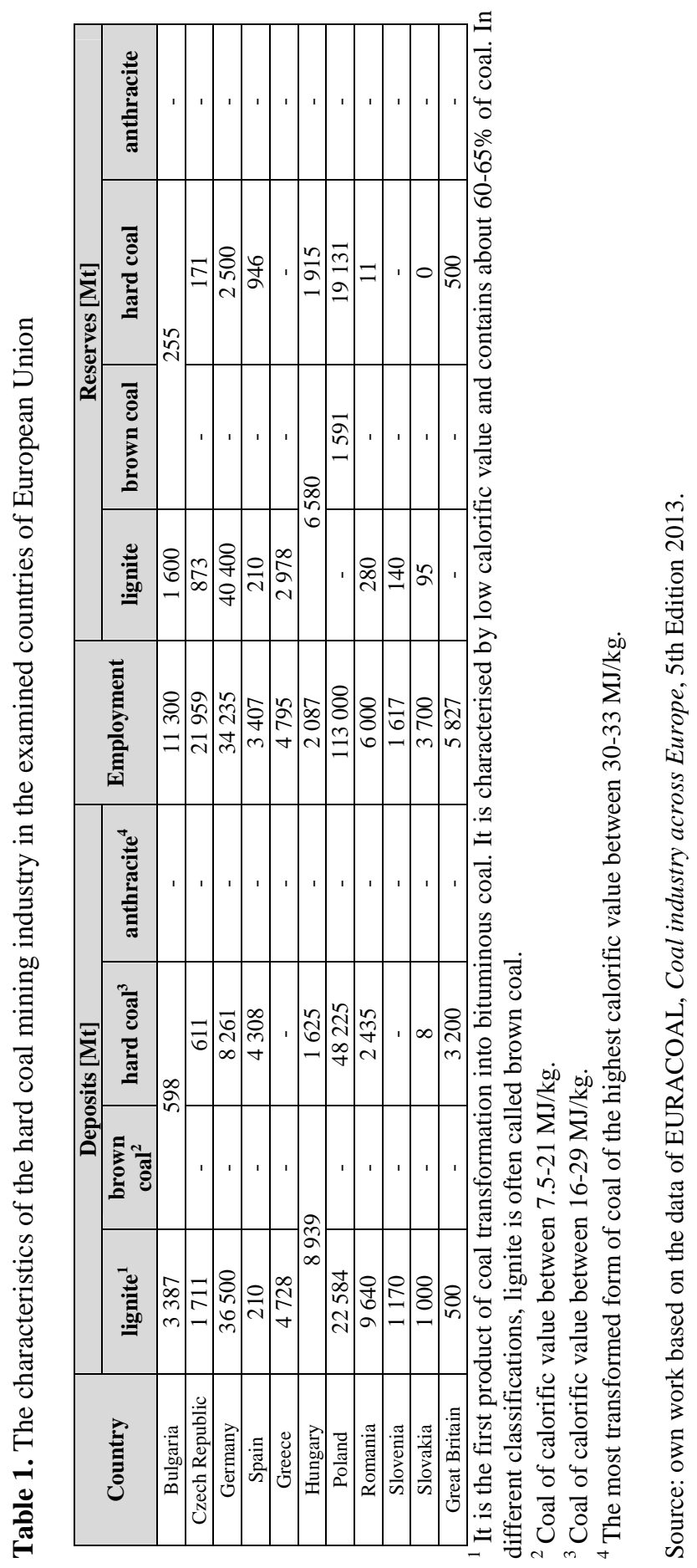


The data from Tables 2 and 3 show that the greatest beneficiaries of state aid for hard coal mining were Germany, Spain (Rabanal, 2009, pp. 4373-4378; Zafrilla, 2014, pp. 715-722) and Poland from 2000-2012 with a share in total aid, respectively, at $51.08 \%, 29.22 \%$ and $10.51 \%$. Furthermore, the period of the most intensive aid for Spanish mining was from 2000-2002; in German mining, it encompassed the years 2001-2003 and in Polish mining it included the years 2002-2004. In all of the cases mentioned, those were the years of dynamic repair restructuring in this industry.

Table 2. Value of state aid for the hard coal mining industry in the countries of European Union (EU-27) from 2000-2012 [in millions of euro]

\begin{tabular}{|c|c|c|c|c|c|c|c|}
\hline \multirow{2}{*}{ Country } & \multicolumn{7}{|c|}{ Years } \\
\hline & 2000 & 2001 & 2002 & 2003 & 2004 & 2005 & 2006 \\
\hline Bulgaria & 0.00 & 0.00 & 2.60 & 2.50 & 11.00 & 9.40 & 6.60 \\
\hline Czech & & & & & & & \\
\hline Republic & 0.00 & 0.00 & 4.70 & 0.20 & 19.60 & 0.40 & 0.00 \\
\hline Germany & 5303.70 & 4645.40 & 7865.30 & 6947.70 & 3278.50 & 2925.30 & 2513.10 \\
\hline Spain & 2882.80 & 6628.30 & 2739.00 & 2586.50 & 2539.30 & 2480.00 & 874.40 \\
\hline France & 1250.60 & 1205.10 & 1182.00 & 1064.60 & 1018.00 & 0.00 & 0.00 \\
\hline Greece & 0.00 & 0.00 & 0.00 & 18.50 & 0.00 & 0.00 & 0.00 \\
\hline Hungary & 20.20 & 22.90 & 13.60 & 12.10 & 110.90 & 42.30 & 34.20 \\
\hline Poland & 462.30 & 843.00 & 526.70 & 5442.00 & 660.90 & 255.10 & 170.00 \\
\hline Romania & 0.00 & 0.00 & 73.20 & 186.70 & 254.60 & 78.80 & 106.80 \\
\hline Slovenia & 14.60 & 0.30 & 20.40 & 18.90 & 16.50 & 16.20 & 16.70 \\
\hline Slovakia & 8.30 & 9.50 & 6.50 & 6.60 & 1.50 & 4.00 & 5.90 \\
\hline $\begin{array}{l}\text { Great } \\
\text { Britain }\end{array}$ & 150.10 & 106.10 & 27.90 & 37.80 & 54.90 & 68.20 & 13.30 \\
\hline Total & 10092.60 & 13460.60 & 12461.90 & 16324.10 & 7965.70 & 5879.70 & 3741.00 \\
\hline \multirow{2}{*}{ Country } & \multicolumn{7}{|c|}{ Years } \\
\hline & 2007 & 2008 & 2009 & 2010 & 2011 & 2012 & Total \\
\hline Bulgaria & 0.00 & 0.00 & 0.00 & 0.00 & 0.00 & 0.00 & 32.10 \\
\hline $\begin{array}{l}\text { Czech } \\
\text { Republic }\end{array}$ & 0.00 & 0.00 & 0.00 & 0.00 & 0.00 & 0.00 & 24.90 \\
\hline Germany & 2460.80 & 1859.30 & 1795.00 & 1796.10 & 1489.80 & 1437.00 & 44317.00 \\
\hline Spain & 842.60 & 819.20 & 780.10 & 825.40 & 804.00 & 551.80 & 25353.40 \\
\hline France & 0.00 & 0.00 & 0.00 & 0.00 & 0.00 & 0.00 & 5720.30 \\
\hline Greece & 0.00 & 0.00 & 0.00 & 0.00 & 0.00 & 0.00 & 18.50 \\
\hline Hungary & 41.30 & 37.10 & 30.90 & 29.30 & 0.00 & 0.00 & 394.80 \\
\hline Poland & 109.60 & 156.30 & 97.80 & 195.90 & 100.10 & 96.30 & 9116.00 \\
\hline Romania & 116.40 & 91.30 & 73.70 & 61.10 & 0.00 & 38.20 & 1080.80 \\
\hline Slovenia & 18.30 & 18.10 & 16.50 & 11.80 & 10.90 & 6.60 & 185.80 \\
\hline Slovakia & 4.10 & 4.00 & 5.50 & 5.00 & 0.00 & 0.00 & 60.90 \\
\hline $\begin{array}{l}\text { Great } \\
\text { Britain }\end{array}$ & 0.50 & 2.20 & 0.00 & 0.00 & 0.00 & 0.00 & 461.00 \\
\hline Total & 3593.60 & 2987.50 & 2799.50 & 2924.60 & 2404.80 & 2129.90 & 86765.50 \\
\hline
\end{tabular}

Source: European Commission (Scoreboard: data on state aid expenditure, http://ec.europa.eu/competition/state_aid/studies_reports/expenditure.html). 
Table 3. The structure of state aid for the hard coal mining industry in the European Union (EU-27) by countries in the years 2000-2012 [in \%]

\begin{tabular}{|c|c|c|c|c|c|c|c|}
\hline \multirow[b]{2}{*}{ Country } & \multicolumn{7}{|c|}{ Years } \\
\hline & 2000 & 2001 & 2002 & 2003 & 2004 & 2005 & 2006 \\
\hline Bulgaria & $0.00 \%$ & $0.00 \%$ & $0.02 \%$ & $0.02 \%$ & $0.14 \%$ & $0.16 \%$ & $0.18 \%$ \\
\hline $\begin{array}{l}\text { Czech } \\
\text { Republic }\end{array}$ & $0.00 \%$ & $0.00 \%$ & $0.04 \%$ & $0.00 \%$ & $0.25 \%$ & $0.01 \%$ & $0.00 \%$ \\
\hline Germany & $52.55 \%$ & $34.51 \%$ & $63.11 \%$ & $42.56 \%$ & $41.16 \%$ & $49.75 \%$ & $67.18 \%$ \\
\hline Spain & $28.56 \%$ & $49.24 \%$ & $21.98 \%$ & $15.84 \%$ & $31.88 \%$ & $42.18 \%$ & $23.37 \%$ \\
\hline France & $12.39 \%$ & $8.95 \%$ & $9.48 \%$ & $6.52 \%$ & $12.78 \%$ & $0.00 \%$ & $0.00 \%$ \\
\hline Greece & $0.00 \%$ & $0.00 \%$ & $0.00 \%$ & $0.11 \%$ & $0.00 \%$ & $0.00 \%$ & $0.00 \%$ \\
\hline Hungary & $0.20 \%$ & $0.17 \%$ & $0.11 \%$ & $0.07 \%$ & $1.39 \%$ & $0.72 \%$ & $0.91 \%$ \\
\hline Poland & $4.58 \%$ & $6.26 \%$ & $4.23 \%$ & $33.34 \%$ & $8.30 \%$ & $4.34 \%$ & $4.54 \%$ \\
\hline Romania & $0.00 \%$ & $0.00 \%$ & $0.59 \%$ & $1.14 \%$ & $3.20 \%$ & $1.34 \%$ & $2.85 \%$ \\
\hline Slovenia & $0.14 \%$ & $0.00 \%$ & $0.16 \%$ & $0.12 \%$ & $0.21 \%$ & $0.28 \%$ & $0.45 \%$ \\
\hline Slovakia & $0.08 \%$ & $0.07 \%$ & $0.05 \%$ & $0.04 \%$ & $0.02 \%$ & $0.07 \%$ & $0.16 \%$ \\
\hline $\begin{array}{l}\text { Great } \\
\text { Britain }\end{array}$ & $1.49 \%$ & $0.79 \%$ & $0.22 \%$ & $0.23 \%$ & $0.69 \%$ & $1.16 \%$ & $0.36 \%$ \\
\hline Total & $100.00 \%$ & $100.00 \%$ & $100.00 \%$ & $100.00 \%$ & $100.00 \%$ & $100.00 \%$ & $100.00 \%$ \\
\hline \multirow{2}{*}{ Country } & \multicolumn{7}{|c|}{ Years } \\
\hline & 2007 & 2008 & 2009 & 2010 & 2011 & 2012 & Total \\
\hline Bulgaria & $0.00 \%$ & $0.00 \%$ & $0.00 \%$ & $0.00 \%$ & $0.00 \%$ & $0.00 \%$ & $0.04 \%$ \\
\hline $\begin{array}{l}\text { Czech } \\
\text { Republic }\end{array}$ & $0.00 \%$ & $0.00 \%$ & $0.00 \%$ & $0.00 \%$ & $0.00 \%$ & $0.00 \%$ & $0.03 \%$ \\
\hline Germany & $68.48 \%$ & $62.24 \%$ & $64.12 \%$ & $61.41 \%$ & $61.95 \%$ & $67.47 \%$ & $51.08 \%$ \\
\hline Spain & $23.45 \%$ & $27.42 \%$ & $27.87 \%$ & $28.22 \%$ & $33.43 \%$ & $25.91 \%$ & $29.22 \%$ \\
\hline France & $0.00 \%$ & $0.00 \%$ & $0.00 \%$ & $0.00 \%$ & $0.00 \%$ & $0.00 \%$ & $6.59 \%$ \\
\hline Greece & $0.00 \%$ & $0.00 \%$ & $0.00 \%$ & $0.00 \%$ & $0.00 \%$ & $0.00 \%$ & $0.02 \%$ \\
\hline Hungary & $1.15 \%$ & $1.24 \%$ & $1.10 \%$ & $1.00 \%$ & $0.00 \%$ & $0.00 \%$ & $0.46 \%$ \\
\hline Poland & $3.05 \%$ & $5.23 \%$ & $3.49 \%$ & $6.70 \%$ & $4.16 \%$ & $4.52 \%$ & $10.51 \%$ \\
\hline Romania & $3.24 \%$ & $3.06 \%$ & $2.63 \%$ & $2.09 \%$ & $0.00 \%$ & $1.79 \%$ & $1.25 \%$ \\
\hline Slovenia & $0.51 \%$ & $0.61 \%$ & $0.59 \%$ & $0.40 \%$ & $0.45 \%$ & $0.31 \%$ & $0.21 \%$ \\
\hline Slovakia & $0.11 \%$ & $0.13 \%$ & $0.20 \%$ & $0.17 \%$ & $0.00 \%$ & $0.00 \%$ & $0.07 \%$ \\
\hline $\begin{array}{l}\text { Great } \\
\text { Britain }\end{array}$ & $0.01 \%$ & $0.07 \%$ & $0.00 \%$ & $0.00 \%$ & $0.00 \%$ & $0.00 \%$ & $0.53 \%$ \\
\hline Total & $100.00 \%$ & $100.00 \%$ & $100.00 \%$ & $100.00 \%$ & $100.00 \%$ & $100.00 \%$ & $100.00 \%$ \\
\hline
\end{tabular}

Source: own work.

After the year 2003, one may also observe the value decrease of total aid for mining in the EU in all of the examined countries. It was caused by a reduction of aid for major beneficiaries, the completion of the most important restructuring activities and, finally, the tightening of the conditions for granting state aid for the mining industry in the year 2010, due to a lack of improvement in the competitiveness of unprofitable hard coal mines, despite state support and violating the rules of free-market competition at the same time (Caputa, 2012, pp. 49-71; Szwajca, 2012, pp. 18-20). 
In order to perform a deeper analysis of the range of state aid for the hard coal mining industry and to take into account the differences in the resource and excavation potential of the examined countries, the value of state aid was calculated per ton of the resource mined in the particular country. The results of the calculation are presented in Table 4 .

Table 4. State aid calculated per ton of the resources mined in the European Union (EU-27) by country from 2000-2012 [in euro/ton]

\begin{tabular}{|c|c|c|c|c|c|c|c|c|}
\hline \multirow{2}{*}{ Country } & \multicolumn{8}{|c|}{ Years } \\
\hline & 2000 & 2001 & 2002 & 20 & 03 & 2004 & 2005 & 2006 \\
\hline Bulgaria & 0.00 & 0.00 & 0.10 & & 0.09 & 0. & 0.38 & 0.26 \\
\hline $\begin{array}{l}\text { Czech } \\
\text { Republic }\end{array}$ & 0.00 & 0.00 & 0.07 & & 0.00 & 0. & 0.01 & 0.00 \\
\hline Germany & 26.39 & 22.95 & 37.78 & & 33.91 & 15. & 14.42 & 12.75 \\
\hline Spain & 122.78 & 292.25 & 124.33 & & 25.93 & 123. & 128.14 & 47.52 \\
\hline France & 305.02 & 436.63 & 585.15 & & 75.27 & 1170. & 0.00 & 0.00 \\
\hline Greece & 0.00 & 0.00 & 0.00 & & 0.26 & 0. & 0.00 & 0.00 \\
\hline Hungary & 1.44 & 1.65 & 1.04 & & 0.91 & 9. & 4.42 & 3.44 \\
\hline Poland & 2.84 & 5.15 & 3.25 & & 33.23 & & 1.60 & 1.09 \\
\hline Romania & 0.00 & 0.00 & 2.41 & & 5.65 & & 2.53 & 3.06 \\
\hline Slovenia & 19.73 & 0.43 & 31.88 & & 30.98 & 27. & 27.46 & 28.31 \\
\hline Slovakia & 2.31 & 2.78 & 1.91 & & 2.14 & 0. & 1.59 & 2.68 \\
\hline $\begin{array}{l}\text { Great } \\
\text { Britain }\end{array}$ & 4.81 & 3.32 & 0.93 & & 1.34 & 2. & 3.33 & 0.72 \\
\hline \multirow{2}{*}{ Country } & \multicolumn{8}{|c|}{ Years } \\
\hline & 2007 & 2008 & 200 & & & & 2011 & 2012 \\
\hline Bulgaria & 0.00 & 0.00 & & 0.00 & & 0.00 & 0.00 & 0.00 \\
\hline $\begin{array}{l}\text { Czech } \\
\text { Republic }\end{array}$ & 0.00 & 0.00 & & 0.00 & & 0.00 & 0.00 & 0.00 \\
\hline Germany & 12.19 & 9.66 & & 9.77 & & 9.85 & 7.90 & 7.33 \\
\hline Spain & 49.05 & 80.29 & & 82.57 & & 97.87 & 122.13 & 88.57 \\
\hline France & 0.00 & 0.00 & & 0.00 & & \begin{tabular}{l|l|}
0.00 \\
\end{tabular} & 0.00 & 0.00 \\
\hline Greece & 0.00 & 0.00 & & 0.00 & & 0.00 & 0.00 & 0.00 \\
\hline Hungary & 4.21 & 3.95 & & 3.44 & & 3.23 & 0.00 & 0.00 \\
\hline Poland & 0.75 & 1.09 & & 0.72 & & 1.47 & 0.72 & 0.67 \\
\hline Romania & 3.25 & 2.55 & & 2.17 & & 1.96 & 0.00 & 1.12 \\
\hline Slovenia & 38.13 & 40.22 & & 37.50 & & 26.82 & 24.22 & 15.35 \\
\hline Slovakia & 1.94 & 1.65 & & 2.14 & & 2.10 & 0.00 & 0.00 \\
\hline $\begin{array}{l}\text { Great } \\
\text { Britain } \\
\end{array}$ & 0.03 & 0.12 & & 0.00 & & 0.00 & 0.00 & 0.00 \\
\hline
\end{tabular}

Source: own work.

The objectified values of state aid only partially confirm the previous conclusions concerning its largest beneficiaries; in a relative approach, they were still Spain (from 48 euro/ton to 292 euro/ton) and Germany (from 7 euro/ton to 38 euro/ton). However, Poland, due to the large range of excavation in the examined group, obtained subsidy for one ton in the amount 
of 0.67 euro to 34 euro. That means that Slovenia had a similar level of state aid from 0.43 euro/ton to 40 euro/ton. It is also worth stressing that France obtained the highest state aid (from 305 euro/ton to 1170 euro/ton) from 2000-2004; however, these were the means fully allocated for the total liquidation of hard coal mining in this country.

\section{Qualitative and Economic Effects of State Aid For Hard Coal Mining in the European Union}

Knowing the scope of state aid for hard coal mining in the examined EU countries, it is worth looking into the quality and economic results attained in this business within the last five years. This is because both qualitative and economic parameters enable the analysis of competitiveness of the examined industry in the particular countries. The basic coal quality assessment parameters are consecutively presented in Table 5 . The first is the lower heating value, the so-called calorific value. This is the heat of combustion reduced by the heat of vaporization of the water formed during coal combustion, as well as created by the hydrogen contained in coal. The calorific value measurement unit is $\mathrm{kJ} / \mathrm{kg}$ or $\mathrm{MJ} / \mathrm{kg}$ (kilojoules or megajoules per kilogram). A higher coal heating value indicates greater usefulness and effectiveness as an energy resource.

The next important quality assessment parameter for coal as an energy resource is the sulfur content in coal, which fluctuates from a few tenths of a percent to $4 \%$. The higher the sulfur content, the worse the coal quality. In the EU, in which great importance is currently attached to clean production of electricity, this parameter is particularly important, due to the continuous tightening of emission restrictions concerning, among others, sulfur compounds.

Ash content, the next coal quality parameter, is perceived similarly. Ash content constitutes ash residue after the roasting of coal. It enables the determination of the coal purity category. There are 5 basic categories:

- high-purity coal with an ash content of less than $10 \%$,

- medium-purity coal with an ash content from 10 to $20 \%$,

- low-purity coal with an ash content from 20 to $30 \%$,

- very low-purity coal with an ash content from 30 to $50 \%$,

- coal slate with an ash content from 50 to $80 \%$.

The coal of the highest quality is characterized by the lowest ash content. 
According to the data presented in Table 5, lignite mined in the Czech Republic, Bulgaria and Germany is specific for the highest calorific value. In the case of hard coal, the highest heating value is presented by coal mined in the Czech Republic, Germany and Great Britain. The average calorific value of hard coal in Spain, one of the leading beneficiaries of state aid, is very low, at just $18231 \mathrm{~kJ}$. Poland, with heating value ranging from $21000 \mathrm{~kJ}$ to $28000 \mathrm{~kJ}$, is located in the middle of the ranking; nevertheless, it should be noted that, in a situation of dropping coal prices on the European market as well as rising expectations in terms of raw materials' quality in the power industry, the average level of calorific value at a high price does not guarantee demand for Polish mining production.

On the other hand, lignite with the lowest sulfur content is mined in Greece, Poland and Slovenia. In the case of hard coal, Czech, British and Polish coal has the lowest sulfur content. The worst quality parameters in terms of sulfur content are characterized by Bulgarian, Romanian and German coal.

In terms of ash content in lignite, the best results are achieved by Poland, Slovenia and Bulgaria (Papagiannis, et al., 2014, pp. 414-424). In the case of hard coal, the lowest ash content is contained in Czech, British and German coal. Polish hard coal has average ash content which, in combination with average sulfur content and calorific value, definitely does not favor the competitiveness of the Polish raw materials on the European market .

Summing up the assessment results of the quality of lignite, it should be stated that the best quality parameters are presented by the Czech and Slovenian lignite. On the other hand, the best-quality hard coal is mined in the Czech Republic, Great Britain and Germany. Among these countries, substantial state aid has been transferred to the German, British and Slovenian mining industry. Czech mining has not been subsidized in such a wide range, and yet it achieves very good quality parameters.

In Table 6, there are parameters characterizing the economic results of hard coal mining in the examined countries. Firstly, in terms of value added, the best results were achieved by the Czech Republic and Great Britain, where the average value added from 2008-2012 exceeded almost seventyfold and sixtyfold respectively the value of state aid transferred to hard coal mining from 2000 to 2012. Good results in this area were also achieved by Greece and Bulgaria. Poland, with an outcome at the level of $80 \%$, is placed in the final section of the ranking. 


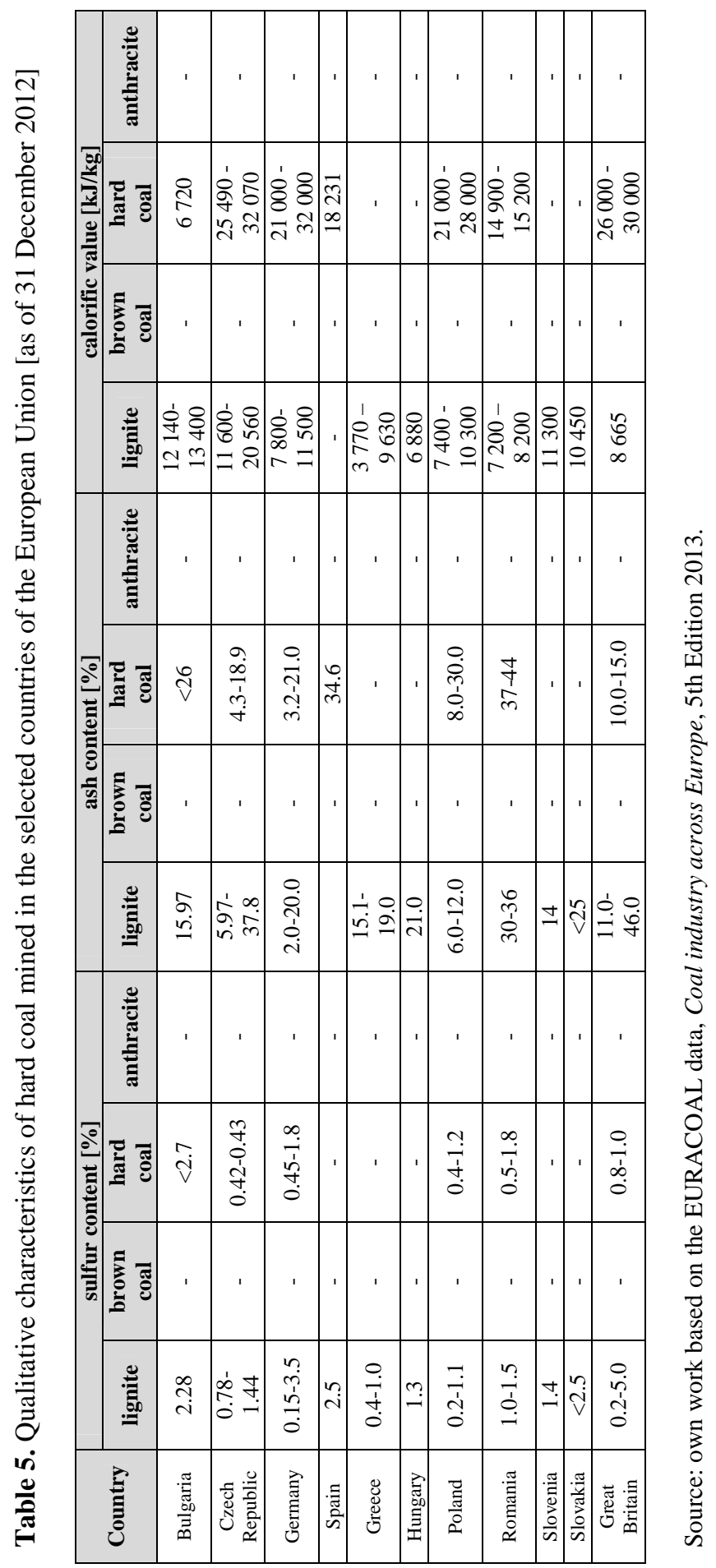




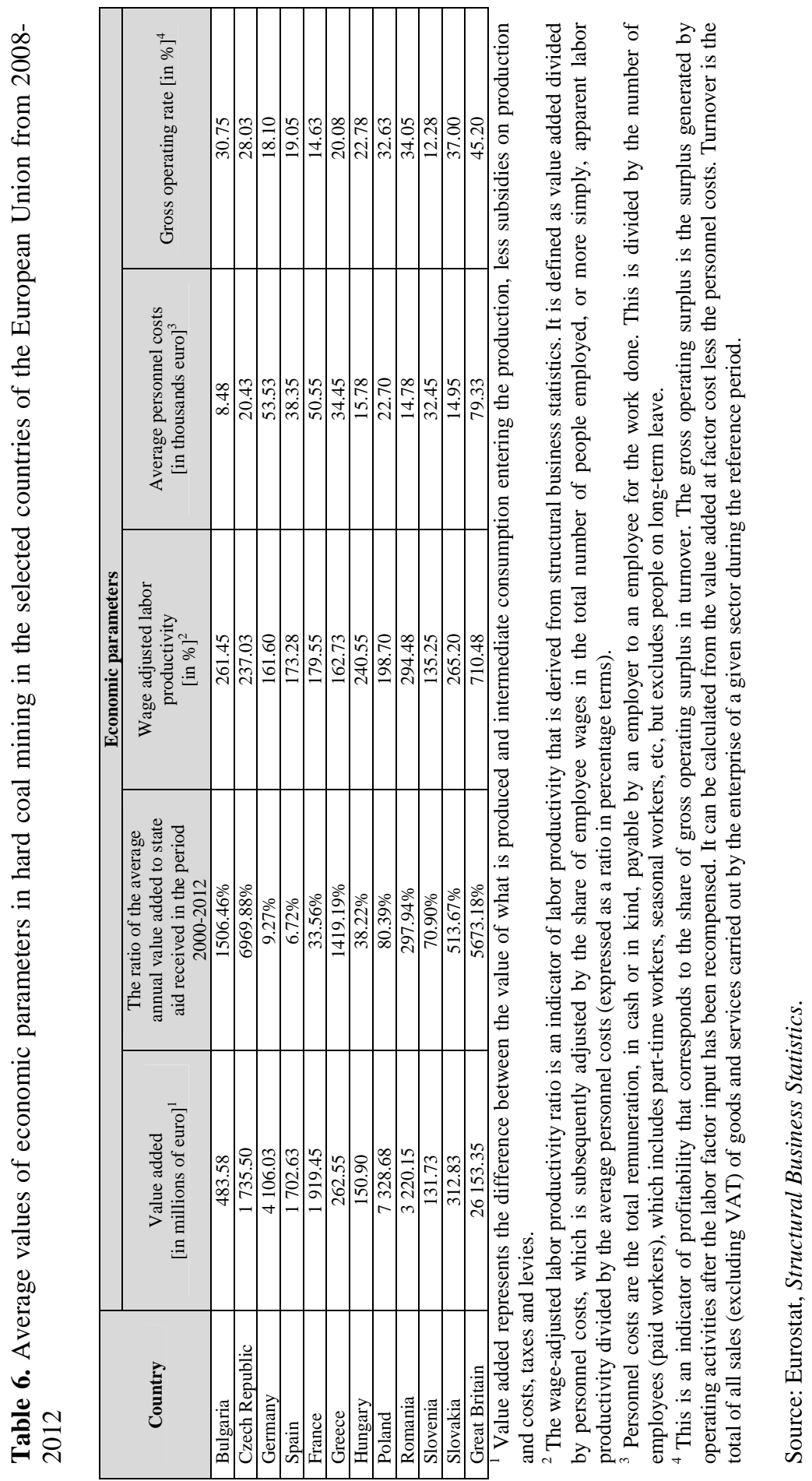


On the other hand, the best ratio of value added to wages is achieved by Great Britain, Romania and Hungary. The last two of these countries owe their high productivity index value above all to low wages.

The highest personnel costs were present in British, German and French coal mining. In this category, Poland comes $7^{\text {th }}$; however, the Czech Republic, Hungary, Romania, Slovakia and Bulgaria follow behind. Therefore, it may be concluded that, compared with countries with a similar level of economic development, personnel costs in the Polish coal mining industry are relatively high (higher costs were observed only in Slovenian mining). The highest gross operating rate was achieved by coal mining in Great Britain, Slovakia and Romania. Poland is in fourth place. However, it is worth emphasizing that Poland's high position in this ranking results from, periodically, very good performance of the industry achieved in the years of prosperity (2009-2010), as well as including brown coal mining in the statistics.

To sum up, the best values of economic parameters in the examined period were achieved by the British, Czech and Slovak hard coal mining industry.

\section{Effectiveness of Polish Hard Coal Mines in the Light of the Current EU Legislations Concerning State Aid}

As was mentioned at the beginning of this document, since 2010 state aid may be granted to the mining industry mostly for the liquidation of permanently ineffective hard coal mines. In order to relate the aforementioned legislations to the current situation of the two largest state-owned mining enterprises, Table 7 presents the gross margin on sales in 24 hard coal mines that belong to these enterprises.

According to data included in Table 7, 10 out of 24 examined mines may be considered to be permanently ineffective since, during the eightyear research period, they achieved a positive gross rate for two years at the most. That means they were able to cover production costs by sales revenues then. Two out of those 10 mines had never been profitable.

It is worth emphasizing that, since 2010, profitability of all the examined mines has been systematically deteriorating. In 2012, only 7 out of 20 existing mines were performing effectively, whereas in 2009 there were 12 such units. The main reason for this crisis in the Polish hard coal mining from 2012-2013 was the uncontrolled increase of unit production costs which was not accompanied by the increase in production efficiency, either 


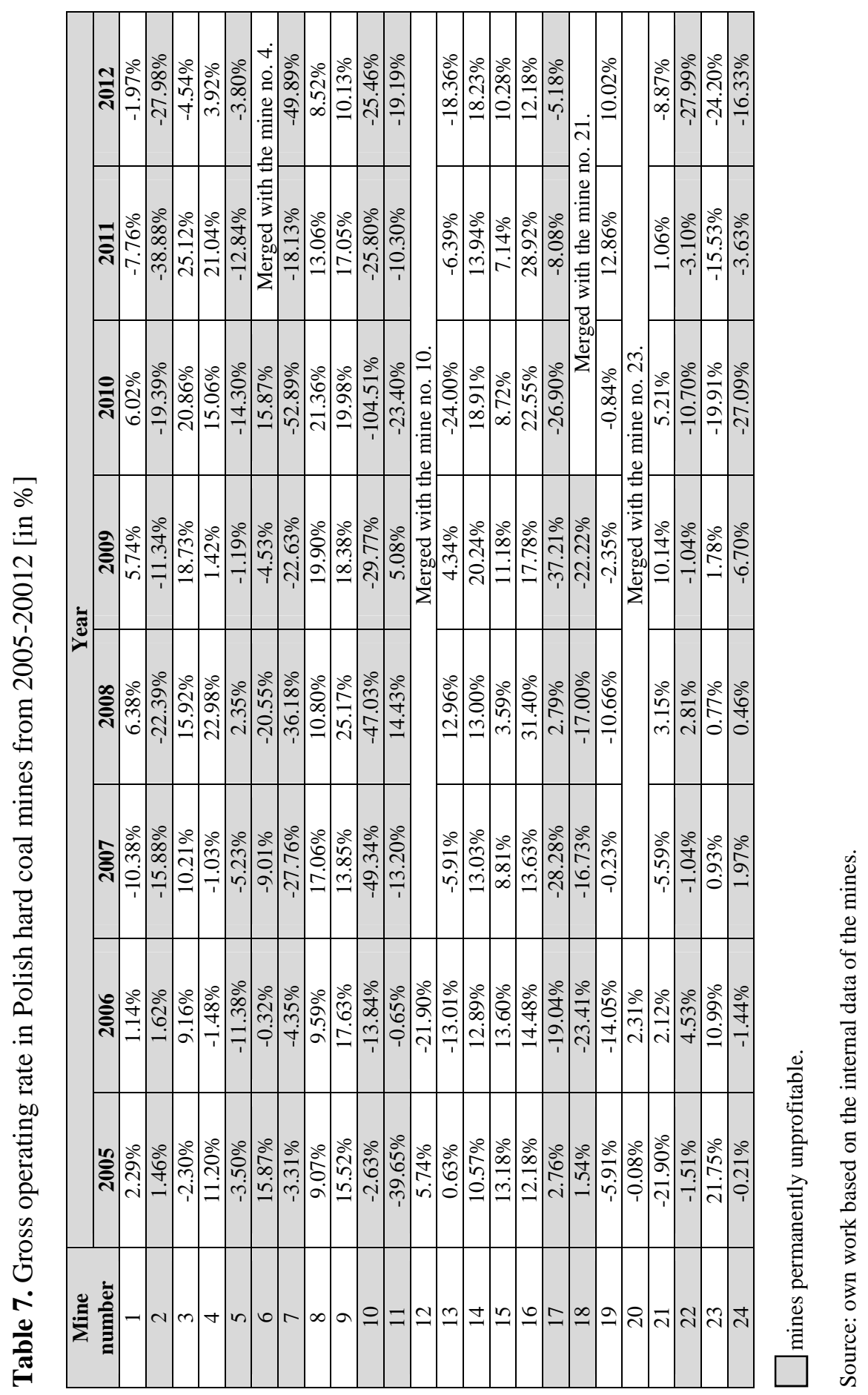


in terms of quality or quantity. The cost increase was driven by an improvement of the economy in 2009-2010 and by price increases of hard coal on the global market.

A periodical improvement of financial results of the examined enterprises escalated the pay demands of trade unions, which translated into economically unjustified pay and production costs increases. Therefore, when hard coal prices decreased, the Polish hard coal mining industry was not able to comply with the price and quality requirements of the leading electricity producers. Cheaper, imported coal appeared on the market $(\mathrm{Ca}-$ puta, 2008, pp. 165-177), which caused problems with sales and financial liquidity (Michalak, 2013, pp. 331-346). These days the examined mining enterprises are seriously threatened with bankruptcy.

\section{Conclusions}

In the first part of the summary, there is a reference to the first research problem discussed in this article, which is formed by the following question: Which countries, from 2000-2012, granted the highest amounts of state aid to the hard coal mining industry and has this found its reflection in the economic and quality results of the examined industries? From an absolute perspective, the greatest state aid was received by Germany, Spain and Poland. From a relative perspective - that is, after calculating state aid per ton of resource mined - the largest beneficiaries of state aid remained Germany and Spain, which were joined by Slovenia, with its small output but also relatively high state aid. Because of the biggest output, Poland was listed in the latter part of this ranking.

In the examined countries, the best results in terms of quality of the extracted resources were obtained by: the Czech Republic, Great Britain, Germany and Slovenia. Among these countries, only Germany and Slovenia were in the group of the three biggest beneficiaries of state aid (in relative terms).

On the other hand, taking into account the economic criteria, the best values of economic parameters in the examined period were attained by the British, Czech and Slovak hard coal mining industry. Three main beneficiaries of state aid were not present among the listed countries. Consequently, it may be stated that the intensity of state aid did not have the desired results reflected in the quality or economic effects of the three largest recipients of state aid in the hard coal mining in the European Union. 
According to above, it could be concluded that state interference in the economy has been largely ineffective and insufficient. The main beneficiaries have not improved their competitiveness and financial results. There are also such countries as Czech and Slovakia that in spite of much less amounts of state aid have managed to reach efficiency in free market conditions.

It is also worth noting that the Polish hard coal mining is characterized by average quality and economic parameters which, in a situation of influx of cheaper and better imported coal, may become a serious threat to the existence of the entire industry. This is confirmed by the results of the effectiveness assessment of the Polish coal mines, which provides an answer to the second research question stated: What are the development perspectives of the Polish hard coal mining in the light of the current EU regulations concerning state aid for the industry and in the context of their current economic situation? Thus, 10 out of the 24 examined mines are mines which may be regarded as permanently unprofitable because in the eightyear research period, they only achieved a positive gross margin in two years; that is, they were able to cover the production costs by sales revenues. Two out of these 10 coal mines had never been profitable. It is also worth emphasizing that, since 2010, the profitability of all of the examined coal mines has consistently deteriorated. In 2012, only 7 out of the 20 existing units worked efficiently, while in 2009, there were 12 such units.

Therefore, taking into account the EU ban on providing state aid to mining enterprises for initial investments, as well as limiting the scope of state aid to cover the costs of the liquidation of unprofitable mines or continuation of the started restructuring activities, it should be concluded that the examined mining enterprises will be forced to close down a dozen or so of the hard coal mines functioning in their structures. These enterprises, despite the considerable public financial support, have failed to improve their competitive position and even partially regain their permanent profitability. State aid granted to the Polish hard coal mining in the analyzed period ultimately turned out to be discouraging, ineffective and inefficient.

\section{References}

Anderson, K. (1995). The political economy of coal subsidies in Europe. Energy Policy 23 (6). http://dx.doi.org/10.1016/0301-4215(95)91229-6.

Apostolov, M. (2011). Corporate governance in Macedonia - micro and macro analysis. Risk Governance and Control: Financial Markets \& Institutions, 1(1).

Apostolov, M. (2013). Governance and enterprise restructuring in Southeast Europe. International Journal of Social Economics, 40(8). 
Balcerzak, A. P. (2009). Efektywność systemu instytucjonalnego a potencjał gospodarki opartej na wiedzy. Ekonomista, 6.

Balcerzak, A. P., \& Rogalska, E. (2010). Government's Effectiveness in Creating Institutional Conditions for Entrepreneurship in Central and Eastern Europe in the Years 2004-2010. In: A. P. Balcerzak (Ed.), Policies for Improving Growth Potential: International Perspective. Torun: Wydawnictwo Naukowe UMK.

Bhattacharyya, S. (2007). Power sector reform in South Asia: Why slow and limited so far?. Energy Policy, 35.

Białas, M. (2011). Pomoc publiczna dla górnictwa węgla kamiennego w świetle nowej decyzji Rady Unii Europejskiej. Materiaty XXIII konferencji z cyklu Zagadnienia surowców energetycznych $i$ energii w gospodarce krajowej, Zakopane.

Caputa, W. (2008). Orientacja na klienta a efektywność wykorzystania zasobów. In: W. Caputa (Ed.). Rachunkowość i finanse podmiotów gospodarczych w erze informacji. Warszawa: CeDeWu.

Caputa, W. (2010). Konkurencyjność przedsiębiorstwa w okresie globalizacji. In: W. Caputa \& D. Szwajca (Eds.). Potencjał konkurencyjny przedsiębiorstwa w warunkach globalizacji. Warszawa: CeDeWu.

Fernández, I. R. (2000). How costly is the maintenance of the coal-mining jobs in Europe? The Spanish case 1989-1995. Energy Policy, 28(8)..

Frondel, M., Kambeck, R., \& Schmidt, Ch., M. (2007). Hard coal subsidies: A never-ending story?. Energy Policy, 35 (7). http://dx.doi.org/10.1016/j.enpo 1.2007.01.019.

Gorczyńska, A. \& Szwajca D. (2012). Financial Aspects of the Competitiveness of the Enterprise. In: S. Hittmar (Ed.). Theory of Management 5: The Selected Problems for the Development Support of Management Knowledge Base. Zilina: University of Zilina.

Kam, A., Citron, D. \& Muradoglu, G. (2008). Distress and restructuring in China: Does ownership matter? China Economic Review, 19(4). http://dx.doi.org/10. 1016/j.chieco.2008.07.002.

Kavouridis, K. (2008). Lignite industry in Greece within a world context: Mining, energy supply and environment. Energy Policy, 36(4). http://dx.doi.org/10.1 016/i.enpol.2007.11.017.

Lorenz, U., Grudziński, Z. (2009). Międzynarodowe rynki węgla kamiennego energetycznego. Kraków: Wydawnictwo Instytutu Gospodarki Surowcami Mineralnymi i Energią PAN.

Michalak, A. (2011). Identyfikacja źródeł finansowania inwestycji rozwojowych przedsiębiorstw górniczych na tle innych branż kapitałochłonnych. In: Zarządzanie finansami. Inwestycje, wycena przedsiębiorstw, zarządzanie wartością, Zeszyty Naukowe Uniwersytetu Szczecińskiego nr 639, seria Finanse, rynki finansowe i ubezpieczenia nr 37. Szczecin: Wydawnictwo Uniwersytetu Szczecińskiego. 
Michalak, A. (2012). Wybrane aspekty finansowania inwestycji rozwojowych w branżach kapitałochłonnych. In: Zarządzanie finansami firm - teoria i praktyka, t. 2, Prace Naukowe Uniwersytetu Ekonomicznego we Wrocławiu nr 271, Wrocław: Wydawnictwo Uniwersytetu Ekonomicznego we Wrocławiu.

Michalak, A. (2013). Strategie finansowania przedsiębiorstw w branżach kapitałochłonnych na przykładzie polskich i światowych przedsiębiorstw górniczych. Zarzadzanie i Finanse - Journal of Management and Finance, 11(1).

Miller, B. G. (2011). Coal as Fuel: Past, Present, and Future. Clean Coal Engineering Technology.

Olkuski, T. (2011). Zasoby węgla kamiennego - najpewniejsze źródło energii. Przegląd Górniczy, 7-8.

Papagiannis, A., Roussos, D., Menegaki, M. \& Damigos, D. (2014). Externalities from lignite mining-related dust emissions. Energy Policy, 74. http://dx.doi.org/10.1016/j.enpol.2014.08.026.

Paszcza, H. \& Białas, M. (2009). Pomoc publiczna dla górnictwa węgla kamiennego - przegląd oraz zagrożenia i perspektywy po 2010 r. Materiały XXIII konferencji z cyklu Zagadnienia surowców energetycznych $i$ energii $w$ gospodarce krajowej, Zakopane.

Piech, K. (2009). Wiedza i innowacje w rozwoju gospodarczym. W kierunku pomiaru i współczesnej roli państwa. Warszawa: Instytut Wiedzy i Innowacji.

Rabanal, N. G. (2009). Coal restructuring in Spain: Continuity and uncertainty? Energy Policy, 37(11). http://dx.doi.org/10.1016/j.enpol.2009.05.052.

Roch, I. (2009). Brown coal planning as a basis for sustainable settlement development. Procedia Earth and Planetary Science, 1(1). http://dx.doi.org/10.1 016/j.proeps.2009.09.134.

Smandek, A. I. (1993). Teorie rynku pracy. Katowice: Wydawnictwo Akademii Ekonomicznej.

Spychalski, G. (2002). Zarys historii myśli ekonomicznej. Warszawa-Łódź: PWN.

Stankiewicz, W. (2000). Historia myśli ekonomicznej. Warszawa: PWN.

Szwajca, D. (2012). Zasoby marketingowe przedsiębiorstwa jako źródło przewagi konkurencyjnej. Gliwice: Wydawnictwo Politechniki Śląskiej.

Wojtyna, A. (2000). Ewolucja keynesizmu a główny nurt ekonomii. Warszawa: PWN.

Zafrilla, J. E. (2014). The mining industry under the thumb of politicians: the environmental consequences of the Spanish. Journal of Cleaner Production, 84. http://dx.doi.org/10.1016/j.jclepro.2014.02.031.

Zieliński, M. (2008). Wptyw państwa na rynek pracy i decyzje zatrudnieniowe przedsiębiorstw. Gliwice: Wydawnictwo Politechniki Śląskiej.

Zieliński, M. (2013). Efektywność -ujęcie ekonomiczne i społeczne. Zeszyty Naukowe Politechniki Ślaskiej, seria: Organizacja i Zarzadzanie, 66. 
